\title{
DAMPAK ALIH FUNGSI LAHAN PERTANIAN KE SEKTOR NON PERTANIAN TERHADAP KETERSEDIAAN BERAS DI KABUPATEN KLATEN PROVINSI JAWA TENGAH
}

\section{THE RATE OF THE AGRICULTURE LAND CONVERSION AND THE IMPACTS OF THE AGRICULTURE LAND CONVERSION TO RICE AVAILABILITY IN KLATEN REGENCY CENTRAL JAVA PROVINCE}

\author{
Catur TB, Joko Purwanto, Rhina Uchyani F dan Susi Wuri Ani \\ Jurusan Agribisnis Fakultas Pertanian UNS
}

\begin{abstract}
ABSTRAK
Tujuan penelitian ini adalah untuk menghitung dampak alih fungsi lahan pertanian ke sektor non pertanian khususnya terhadap ketersediaan beras di kabupaten Klaten. Data sekunder penggabungan dari periode dari 1998 - 2007 pada 26 daerah di kabupaten Klaten. Model penelitian menggunakan analisa perkembangan dan perbedaan dari penghasilan jaring untuk jumlah konsumsi (NPKt). Hasil dari penelitian adalah laju pertumbuhan mencapai ,53\% dan 47\% per tahun. Nilai Konversi rendah adalah nilai positif dari perbedaan penghasilan dengan jumlah konsumsi (NPKt) di kabupaten Klaten.
\end{abstract}

Kata Kunci: alih fungsi lahan, Ketersediaan beras, kabupaten Klaten

\section{ABSTRACT}

The objective of this research were to calculate the rate of the agriculture land conversion and the impacts of the agriculture land conversion to rice availability in Klaten Regency. This research used secondary data (pool data) in periode of 1998-2007 twenty six districts. The models used in this research were growth analysis and difference of net production to total consumption (NPKt). The result of this research show that the growth rate of the low land and up land area in Klaten regency were $-0,53 \%$ and $0,47 \%$ per year. Low land conversion was show positive value of the difference of net production to total consumption (NPKt) in Klaten Regency.

Keywords : agriculture land conversion, rice availability, Klaten Regency

\section{PENDAHULUAN}

Lahan merupakan sumberdaya alam strategis bagi pembangunan. Hampir semua sektor pembangunan fisik memerlukan lahan, seperti sektor pertanian, kehutanan, perumahan, industri, pertambangan dan transportasi. Di bidang pertanian, lahan merupakan sumber daya yang sangat penting, baik bagi petani maupun bagi pembangunan pertanian. Hal ini didasarkan pada kenyataan bahwa di Indonesia kegiatan pertanian masih bertumpu pada lahan (land based agricultuAre activities).

Sektor pertanian yang merupakan sektor dominan memberi sumbangan berarti bagi perekonomian Jawa Tengah sebesar 20,43\% dengan pertumbuhan riil sebesar 2,78\%. Pada tahun 2007, provinsi ini mampu menghasilkan 8,44 juta ton padi sawah pada saat terjadi peyusutan lahan sawah sebesar 0,16 \% sedangkan luas lahan bukan sawah mengalami peningkatan 0,07\% (Anonim, 2008).

Dalam beberapa dekade ini, Provinsi Jawa Tengah menjadi salah satu penopang produksi beras nasional, disamping Jawa Barat dan Jawa Timur. Kabupaten Klaten merupakan salah satu penghasil beras utama di provinsi Jawa Tengah yang terkenal dengan beras Delanggu.

Akhir-akhir ini, sejalan dengan meningkatnya taraf hidup dan terbukanya kesempatan untuk menciptakan peluang kerja yang ditandai oleh banyaknya investor ataupun masyarakat dan pemerintah dalam melakukan pembangunan, semakin meningkat kebutuhan akan lahan. Peningkatan kebutuhan lahan didorong oleh peningkatan jumlah penduduk, sementara ketersediaan dan luas lahan bersifat tetap. Hal ini mengakibatkan terjadinya realokasi penggunaan lahan dari aktivitas yang kurang menguntungkan pada aktivitas yang lebih 
menguntungkan. Aktivitas yang selalu terancam terutama adalah aktivitas pertanian yang dinilai kurang menguntungkan dibanding aktivitas ekonomi lainnya.

Korbanan ekonomi dan sosial alih fungsi lahan pertanian di nilai sangat besar mengingat tingginya biaya investasi dan lamanya waktu yang dibutuhkan sejak awal waktu pembentukkan sawah sampai terbentuknya lahan sawah dengan tingkat produktivitas yang cukup tinggi. Beban alih fungsi lahan bagi pembangunan pertanian dirasa semakin berat karena menyangkut Pertambahan penduduk memerlukan lahan yang semakin luas, tidak saja guna perluasan pemukiman namun juga sebagai ruang perluasan kegiatan-kegiatan perekonomian agar kebutuhan manusia dapat terpenuhi secara lebih baik. Permasalahan timbul ketika penduduk membangun tempat pemukiman serta prasarana pendukungnya pada region pertanian yang subur. Tabel 2 menunjukkan luas penggunaan lahan bukan sawah di Kabupaten Klaten antara tahun 1998 sampai 2007.

Lahan pertanian produktif merupakan aset penting dalam pembangunan pertanian. Hal ini didasarkan atas dua hal yaitu besarnya biaya investasi dalam bentuk sarana dan prasarana irigasi dan pencetakan sawah baru serta lamanya waktu yang dibutuhkan sejak awal pencetakan sawah sampai terbentuknya lahan sawah dengan tingkat produktivitas yang tinggi.

Pada kondisi adanya pilihan terbuka bagi para investor untuk menanamkan modalnya maka alih fungsi lahan pertanian pada daerah dengan infrastruktur yang baik dan sekaligus sebagai pusat pasar yang besar tidak dapat dihindarkan. Persoalan sumber daya lahan yang dinilai cukup serius belakangan ini adalah alih fungsi lahan produktif yang cukup besar. Alih fungsi lahan berlangsung secara terus menerus sejalan dengan peningkatan pembangunan yaitu untuk keperluan bidang industri, pariwisata, pemukiman dan sebagainya.

Transformasi ekonomi yang ditandai pergeseran peran antar sektor menuntut alih fungsi lahan pertanian dalam jumlah yang tidak sedikit. Kasus alih fungsi lahan pertanian di daerah dengan produktivitas rendah tidaklah terlalu mengancam produksi pangan. Namun ketika alih fungsi lahan pertanian menjadi kawasan non pertanian terjadi di lahan beririgasi dengan produktivitas tinggi maka hal ini merupakan ancaman bagi ketersediaan pangan khususnya bahan makanan pokok penduduk (beras). Tulisan ini bertujuan untuk mengidentifikasi tingkat perkembangan alih fungsi lahan pertanian serta dampak alih fungsi pemanfaatan lahan pertanian produktif serta terjadi di daerah dengan aksesibilitas fisik dan ekonomi yang baik.

Alih fungsi lahan pertanian telah menjadi isu global tidak hanya di negara berkembang yang masih bertumpu pada sektor pertanian, namun juga di negara maju untuk menghindari ketergantungan terhadap impor produk pertanian. Dalam prosesnya, alih fungsi lahan pertanian senantiasa berkaitan erat dengan ekspansi atau perluasan kawasan perkotaan.

lahan pertanian terhadap ketersediaan beras di Kabupaten Klaten.

Tabel 1. Perubahan Lahan Sawah Selama Sepuluh Tahun Terakhir di Kabupaten Klaten Tahun 1998-2007 (Ha)

\begin{tabular}{|c|c|c|c|}
\hline Tahun & $\begin{array}{c}\text { Luas Lahan } \\
\text { Sawah }\end{array}$ & $\begin{array}{c}\text { Luas Lahan } \\
\text { Bukan } \\
\text { Sawah }\end{array}$ & $\begin{array}{c}\text { Penyusutan } \\
\text { Luas } \\
\text { Lahan Sawah }\end{array}$ \\
\hline 1998 & 33.838 & 31.718 & - \\
2000 & 33.670 & 31.886 & 168 \\
2002 & 33.636 & 31.920 & 34 \\
2004 & 33.541 & 32.015 & 95 \\
2007 & 33.435 & 32.121 & 106 \\
\hline
\end{tabular}

Sumber : Kabupaten Klaten Dalam Angka, 1998-2007

Tabel 2. Luas Penggunaan Lahan Bukan Sawah di Kabupaten Klaten Tahun 1998-2007 (Ha)

\begin{tabular}{|c|c|c|c|}
\hline Tahun & $\begin{array}{c}\text { Bangunan/ } \\
\text { Pekarangan }\end{array}$ & $\begin{array}{c}\text { Tegal/ } \\
\text { Kebun }\end{array}$ & $\begin{array}{c}\text { Ladang/ } \\
\text { Huma }\end{array}$ \\
\hline 1998 & 19.742 & 6.575 & 0 \\
2000 & 19.016 & 6.222 & 144 \\
2002 & 19.779 & 6.321 & 28 \\
2004 & 19.933 & 6.316 & 0 \\
2007 & 19.995 & 6.287 & 0 \\
\hline
\end{tabular}

Sumber : Kabupaten Klaten Dalam Angka, 1998-2007

\section{METODOLOGI PENELITIAN}

Penelitian ini menggunakan metode dasar deskriptif yaitu suatu metode dalam meneliti sekelompok manusia, suatu objek, suatu set kondisi, suatu sistem pemikiran atau suatu kelas peristiwa pada masa sekarang. Penelitian deskriptif bertujuan untuk membuat deskripsi, Gambaran atau lukisan secara otomatis, faktual dan akurat mengenai fakta-fakta, sifat-sifat serta hubungan antar fenomena yang diselediki (Nazir, 1983).

Penelitian dilakukan di 26 kecamatan di Kabupaten Klaten Provinsi Jawa Tengah dengan pertimbangan bahwa kabupaten ini merupakan salah satu produsen beras di Provinsi Jawa Tengah dengan perkembangan ekonomi yang cukup pesat. Data yang dipergunakan adalah kombinasi antara time series data dan cross section data (pooling data) dengan periode 
pengamatan tahun 1998-2007. Analisis yang dipergunakan :

1. Tingkat perkembangan alih fungsi lahan pertanian (sawah dan tegal) ke arah penggunaan non pertanian dihitung dengan menggunakan metode analisis pertumbuhan $\mathrm{y}_{\mathrm{t}}=\mathrm{y}_{0} \mathrm{e}^{\mathrm{rt}}$ atau $\ln \mathrm{y}=\ln \mathrm{Yo}+\mathrm{rt}$, keterangan : $\mathrm{y}_{\mathrm{t}}=$ luas lahan pertanian (sawah dan tegal) pada tahun $\mathrm{t}, \mathrm{y}_{0}=$ nilai trend periode dasar, $\mathrm{r}$ $=$ pertumbuhan luas lahan pertanian (sawah dan tegal) per tahun dan $\mathrm{t}=$ waktu/tahun

2. Tingkat swasembada pangan khususnya beras digunakan nisbah antara produksi neto dengan total konsumsi (NPKt)

$$
\mathrm{NPKt}=\text { produksi neto }- \text { total konsumsi }
$$

\section{HASIL DAN PEMBAHASAN}

Tingkat Pertumbuhan Lahan Sawah

Kabupaten Klaten dengan luas wilayah 65.556 ha, terdiri atas $51 \%$ (33.435 ha) lahan sawah dan 49\% lahan tegal (32.121 ha). Luas lahan sawah di Kabupaten Klaten pada tahun 1998 adalah 33.827,9 ha. Pada tahun 2007, luas sawah di daerah ini tinggal 33.435 ha atau berkurang 392,9 ha.

Tabel 3. Rata-Rata Luas Lahan dan Tingkat Pertumbuhan Lahan Pertanian Dirinci Per Kecamatan di Kabupaten Klaten Tahun 1998-2007 (Ha)

\begin{tabular}{rlrrrr}
\hline \multirow{2}{*}{ No } & \multirow{2}{*}{ Kecamatan } & \multicolumn{2}{c}{ Luas Rata-Rata (Ha) } & \multicolumn{2}{c}{ Tingkat Pertumbuhan/th (\%) } \\
\cline { 3 - 6 } & & \multicolumn{1}{c}{$\begin{array}{c}\text { Lahan } \\
\text { Sawah }\end{array}$} & Lahan Tegal & Lahan Sawah & Lahan Tegal \\
\hline 1 & Prambanan & 1293.88 & 1149.12 & -0.887 & 1,119 \\
2 & Gantiwarno & 1626.81 & 937.24 & -0.019 & 0,028 \\
3 & Wedi & 1559.3 & 878.7 & -0.032 & 0,057 \\
4 & Bayat & 817.3 & 3125.7 & -0.024 & 0,006 \\
5 & Cawas & 2321.7 & 1125.3 & -0.026 & 0,053 \\
6 & Trucuk & 1929.4 & 1451.6 & -0.216 & 0,293 \\
7 & Kalikotes & 755.8 & 544.2 & -0.053 & 0,073 \\
8 & Kebonarum & 731.5 & 234.5 & -0.191 & 0,603 \\
9 & Jogonalan & 1590.6 & 1079.2 & -0.025 & 0,037 \\
10 & Manisrenggo & 1514.7 & 1181.34 & -0.040 & 0,049 \\
11 & Karangnongko & 765.7 & 1908.3 & -0.026 & 0,010 \\
12 & Ngawen & 1071.9 & 625.16 & 0.046 & 0,352 \\
13 & Ceper & 1579.5 & 865.5 & -0.070 & 0,127 \\
14 & Pedan & 886.9 & 1030.1 & -0.090 & 0,078 \\
15 & Karangdowo & 2051.7 & 871.3 & -0.020 & 0,046 \\
16 & Juwiring & 2016.8 & 962.2 & -0.070 & 0,146 \\
17 & Wonosari & 2255.9 & 859.6 & 0.000 & 0,174 \\
18 & Delanggu & 1337.5 & 540.5 & -0.112 & 0,280 \\
19 & Polanharjo & 1831.8 & 552.2 & -0.022 & 0,072 \\
20 & Karanganom & 1695.4 & 710.6 & -0.047 & 0,113 \\
21 & Tulung & 1743.3 & 1456.7 & -0.040 & 0,048 \\
22 & Jatinom & 609.4 & 2943.6 & -0.033 & 0,007 \\
23 & Kemalang & 53.2 & 5112.8 & 0.385 & $-0,004$ \\
24 & Klaten Selatan & 862.9 & 581.1 & -0.429 & 0,637 \\
25 & Klaten Tengah & 338.9 & 551.1 & -0.129 & 0,097 \\
26 & Klaten Utara & 400.7 & 637.3 & -1.271 & 0,827 \\
\hline Swyyyyy & A & & & &
\end{tabular}

Sumber : Analisis Data Sekunder

Tabel 4. Hasil Analisis Tingkat Pertumbuhan Luas Lahan Sawah di Kabupaten Klaten Tahun 1998-2007

\begin{tabular}{clll}
\hline Parameter & Koefisien & t-hitung & p \\
\hline Konstanta & 6.968047 & 43.5383 & 0.000 \\
$\mathrm{r}$ & -0.52626 & 5.89436 & 0.000 \\
$\mathrm{R}^{2}$ & & 0.999 & \\
\hline
\end{tabular}

Sumber : Analisis Data Sekunder 
Tabel 5. Hasil Analisis Tingkat Pertumbuhan Luas Lahan Tegal di Kabupaten Klaten Tahun 1998-2007

\begin{tabular}{cccc}
\hline Parameter & Koefisien & t-hitung & p \\
\hline Konstanta & 6.885113 & 57.4663 & 0 \\
$\mathrm{r}$ & 0.472245 & 6.9116 & 0 \\
$\mathrm{R}^{2}$ & & 0.999 & \\
\hline
\end{tabular}

Sumber : Analisis Data Sekunder

Dari tabel 3 tampak bahwa penurunan luas lahan sawah terjadi hampir di setiap kecamatan di Kabupaten Klaten. Terdapat 3 kecamatan dengan tingkat pertumbuhan positif (terjadi pertambahan luas lahan sawah) yaitu Kecamatan Kemalang, Kecamatan Ngawen dan Kecamatan Wonosari.

Perubahan luas lahan sawah di Kecamatan Klaten Selatan, Klaten Tengah, Klaten Utara, Trucuk, Prambanan dan Kemalang relatif tinggi dibandingkan daerah lain. Wilayah Klaten Selatan, Tengah dan Utara yang merupakan kawasan perkotaan menuntut kebutuhan akan lahan yang tinggi untuk kebutuhan industri, perumahan maupun jasa. Pada tahun 2007, tercatat terdapat 208 penerbitan sertifikat Hak Guna Bangunan (HGB) di Kecamatan Klaten Selatan (Anonim, 2008).

Berdasarkan kriteria statistik Tabel 4, tingkat pertumbuhan luas lahan sawah di Kabupaten Klaten di atas cukup "reliable". Nilai koefisien determinasi $\left(\mathrm{R}^{2}\right)$ sebesar 99,9\% berarti variabel bebas waktu (t) dapat menerangkan 99,9\% dari perubahan luas lahan sawah di Kabupaten Klaten. Sebanyak 0,1\% dari perubahan luas lahan sawah di Kabupaten Klaten ditentukan oleh variabel lain yang tidak masuk dalam model. Hasil analisis regresi menunjukkan bahwa tingkat pertumbuhan luas lahan berpengaruh negatif pada luas lahan sawah. Koefisien pertumbuhan luas lahan sawah sebesar - 0,53 dengan t hitung 5,89 ( $p<0,01$ ). Artinya jika terjadi perubahan tingkat pertumbuhan luas lahan sawah sebesar 1\% maka akan menyebabkan perubahan pada luas lahan sawah sebesar 0,53 \%. Koefisien pada konstanta 6,96 ( t hitung 43,53) dengan $\mathrm{p}<0,01$ berarti jika tidak ada perubahan tingkat pertumbuhan lahan sawah, maka luas lahan sawah memiliki nilai trend pertumbuhan sebesar 6,96 \%.

Berdasarkan kriteria statistik Tabel 5, tingkat pertumbuhan luas lahan tegal di Kabupaten Klaten di atas cukup "reliable”. Nilai koefisien determinasi $\left(\mathrm{R}^{2}\right)$ sebesar 99,9\% berarti variabel bebas waktu (t) dapat menerangkan 99,9\% dari perubahan luas lahan tegal di Kabupaten Klaten. Sebanyak 0,1\% dari perubahan luas lahan tegal di Kabupaten Klaten ditentukan oleh variabel lain yang tidak masuk dalam model.
Hasil analisis regresi menunjukkan bahwa tingkat pertumbuhan lahan tegal berpengaruh positif pada luas lahan tegalan. Koefisien perubahan luas lahan tegal sebesar 0,47 dengan $t$ hitung 6,91 ( $p<0,01)$ berarti setiap terjadi perubahan tingkat pertumbuhan luas tegal sebesar $1 \%$ akan menyebabkan perubahan luas lahan tegal sebesar $0,47 \%$. Koefisien pada konstanta 6,88 dengan nilai thitung 57,46 ( $\mathrm{p}<0,01$ ) berarti tanpa ada perubahan tingkat pertumbuhan luas lahan tegal, rata-rata luas lahan tegal memiliki nilai trend pertumbuhan sebesar 6,9\%.

\section{Dampak Alih Fungsi Lahan Pertanian}

Luas panen padi sawah di Kabupaten Klaten pada tahun 1998 adalah 65.117 ha. Selama 10 tahun, luas panen padi sawah di kabupaten ini berkurang 7.010 ha menjadi 58.107 ha. Data tahun 2007 menunjukan bahwa luas panen padi sawah terluas terdapat di Kecamatan Karangdowo dan Cawas masingmasing sebesar 4.769 ha dan 4.701 ha. Luas panen padi sawah di Kecamatan Delanggu yang terkenal dengan Beras Delanggu sebesar 3.477 ha. Ditinjau dari luas tanah sawah pada tahun 2007, Kecamatan Cawas memiliki areal persawahan seluas 2.318 ha lebih luas dari luas areal persawahan Kecamatan Karangdowo yaitu 2.049 ha.

Penurunan luas panen padi sawah di Kabupaten Klaten berkaitan dengan penurunan luas tanam produk tersebut yang mengalami penurunan sebanyak 0,78\% pada tahun 2007 bila dibandingkan dengan tahun 2006. Penurunan ini tidak terlepas dari tingkat penyusutan lahan sawah yang relatif besar (Tabel 4). Luas lahan tegal di Kabupaten Klaten pada tahun 1998 adalah 31.728,8 ha. Penanaman padi ladang terdapat di 3 kecamatan yaitu Tulung, Jatinom dan Kemalang. Dari jumlah itu, luas tegal yang ditanami padi ladang berkisar 391 ha. Selama 10 tahun terakhir, luas panen padi ladang di kabupaten ini meningkat 7 ha menjadi 398 ha.

Secara umum, selama tahun 1998 - 2006, Kabupaten Klaten mengalami penurunan produksi padi sawah sebanyak 19.661 ton. Penurunan produksi padi sawah tidak terlepas dari faktor alih fungsi lahan pertanian ke sektor non pertanian. Hal ini terjadi karena lahan 
merupakan faktor utama dalam proses usahatani yaitu sebagai tempat pelaksanaan usahatani. Jika faktor lain dianggap konstan, maka penurunan luas tanam akan menurunkan tingkat produksi padi sawah.

\section{Tingkat Ketersediaan Beras}

Tingkat swasembada pangan dianalisis dengan metode NPKt yaitu selisih produksi netto dengan total konsumsi. Produksi netto merupakan total produksi padi sawah dan padi tegal selama satu tahun. Sedangkan total konsumsi mencakup konsumsi masyarakat Klaten terhadap beras lokal dan beras ketan. Dengan asumsi tingkat konversi padi menjadi beras $63,2 \%$ dan tingkat konsumsi rata-rata 0,2 kg/jiwa/hari, tingkat ketersediaan beras disajikan pada Tabel 6. Dari Tabel 6 tampak bahwa nilai rata-rata $\mathrm{NPK}_{\mathrm{t}}$ Kabupaten Klaten bernilai positif sepanjang tahun. Hal ini menunjukkan selama 10 tahun terakhir Kabupaten Klaten mampu mencukupi kebutuhan beras dalam negri tanpa harus melakukan impor dari wilayah lain.

Tabel 6. Tingkat Ketersediaan Beras di Kabupaten Klaten Tahun 1998-2006

\begin{tabular}{cccc}
\hline Tahun & Produksi/th $(\mathrm{kg})$ & Konsumsi/th $(\mathrm{kg})$ & NPKt $(\mathrm{kg})$ \\
\hline 1998 & 234.013 .572 & 90.090 .249 & 143.923 .323 \\
1999 & 208.288 .346 & 90.717 .903 & 117.570 .443 \\
2000 & 242.742 .984 & 91.810 .786 & 150.932 .198 \\
2001 & 203.769 .440 & 92.366 .535 & 111.402 .905 \\
2002 & 194.719 .200 & 92.821 .690 & 101.897 .510 \\
2003 & 189.390 .808 & 93.242 .681 & 96.148 .127 \\
2004 & 196.693 .568 & 93.570 .378 & 103.123 .190 \\
2005 & 198.329 .184 & 93.882 .234 & 104.446 .950 \\
2006 & 221.587 .416 & 94.406 .666 & 127.180 .750 \\
\hline
\end{tabular}

Sumber :Analisis Data Sekunder

\section{KESIMPULAN}

1. Proses alih fungsi lahan sawah menjadi lahan tegal atau dialihfungsikan ke sektor non pertanian menyebabkan luas lahan sawah di Kabupaten Klaten semakin menyusut (tingkat penyusutan lahan sawah $=0,53 \% /$ tahun). Terjadinya penyusutan luas lahan sawah diikuti dengan pencetakkan lahan tegal baru (tingkat pertumbuhan lahan tegal $=0,47 \%$ / tahun).

2. Walaupun terjadi proses alih fungsi lahan pertanian sepanjang tahun, namun Kabupaten Klaten mampu memenuhi kebutuhan pangan pokok (beras) penduduknya, bahkan terdapat surplus yang dapat diekspor ke luar daerah. Hal ini terbukti dari nilai $\mathrm{NPK}_{\mathrm{t}}$ yang positif sepanjang periode penelitian.

\section{DAFTAR PUSTAKA}

Anonim. 1998 - 2007. Klaten Dalam Angka. BPS Klaten

Anonim. 2007. Jawa Tengah Dalam Angka. BPS Jawa Tengah

Ashari. 2003. Tinjauan Tentang Alih Fungsi Lahan Sawah ke Non Sawah dan Dampaknya di Pulau Jawa. Agro Ekonomi $21(2): 83-97$

Barish, N. 1962. Economics Analysis. Mc Graw Hill Book Company, Inc

Casavant, K.L dan Infanger C. 1984. Economics and Agricultural Management. Reston Publishing Company. Virginia

Irawan, B. 2005. Konversi Lahan Sawah : Potensi Dampak, Pola Pemanfaatannya dan Faktor Determinan. Agro Ekonomi 23(1) : 1 - 18

Kustiwan, I. 1997. Alih Fungsi Lahan Pertanian di Pantai Utara Jawa. Prisma XXVI (1) : $15-32$

Nazir, M. 1983. Metode Penelitian. Ghalia Indonesia. Jakarta

Suherman, M. 2004. Analisa Alih Fungsi Lahan Pertanian dan Pengaruhnya Terhadap Produksi Padi, Jagung dan Kedelai di Propinsi DIY. Tesis Pasca Sarjana UGM 